\title{
Improving Students' Motivation in Learning English Through Cooperative Learning Strategy by Using Media
}

\author{
Mandra Saragih 1 , Ratih Utami ${ }^{2}$ \\ University of Muhammadiyah Sumatera Utara \\ e-mail : mandrasaragih@umsu.ac.id, Daengrasta1984@mail.com
}

\begin{abstract}
This study deals with the improvement of students' motivation in learning English through cooperative learning strategy assisted by attractive media. This study was conducted at SD Muhammadiyah 2 Medan, which located on Jl. Mustafa. No.1, Glugur Darat I, Medan Timur. The subject of the study is the grade six of 2019/2020 academic year. Classroom action research is applied in this study consist of two cycles, in which each cycle consists of four stages; planning, action, observation, and reflection. The data are obtained from both of observation and test. The qualitative data is analyzed through Miles and Huberman approach, while quantitative data is figured out through the formula $P=\frac{\mathrm{R}}{\mathrm{T}} \mathrm{x} 100 \%$. The result denotes that there are only 21 out of 43 students achieve 75 and over in cycle 1, whereas in cycle 2 there is significantly increasing number of students passing 75 and over with 43 students or 100\%. In addition, learning activities become more active and creative. It is inferred that there was significant improvement on students' motivation in learning English through cooperative learning strategy.
\end{abstract}

Key Words: $\quad$ Students' Motivation, English Learning and Cooperative Learning Strategy.

\section{BACKGROUND}

Motivation aims to improve someone's desire, boost someone's willingness become the strong effort by which directed toward a goal. It also plays significant role in academic area such as learning activities in the classroom where someone will succeed in learning if they have a will to learn. Motivation is an important factor in the student learning process (Zimmerman, 2000). Consequently, highly motivated learners have been found to have higher achievement in learning English as a second language than those with lower motivation. According to the theory of motivation, expectations of success relate to three factors, i.e.: how student gives attribution to previous successes and failures, how student interprets their competence, and how student maintains self-esteem.

Learning English as a second language is not only learning a subject matter but the learner has to also engage in culture learning, motivation then plays a key role in the learning process (Dörnyei, 2001; Gardner, 2007). Motivation 'kick starts' the process, 'lubricates' the parts, and 'fuels' the engine to keep it running. Without motivation, learners may not start the act of learning at all and for those who have started to learn, they may not be able to maintain their learning once experiencing hardship in the process (Dörnyei, 2001; Gardner, 2007; Palmer, 2009). Consequently, highly motivated learners have been found to have higher achievement in learning English as a second language than those with lower motivation (Bernaus \& Gardner, 2008; Bernaus, Wilson, \& Gardner, 2008; Fan \& Feng, 2012; Kitjaroonchai, 2012). In EFL contexts where motivation to learn English is driven mainly from external sources and exposure to English outside the classroom is somewhat limited (Al shlowiy, 2014; Cho, 2013; Hayes, 2014), teachers can play an important role in enhancing or undermining students' motivation.

Dornyei (2001) believes that the complexity of the idea of motivation lies in its attempts to elaborate person's actions on behavior which cannot be explained by just one approach. The difficulty as Dornyie (1996) states is not the lack of theories to explain motivation but the plenty of theories and models. Fortunately, there is now a lot of research literature available on the role of motivation in language learning. According to Pourhosein Gilakjani, Leong, and Saburi (2012), the 
success of any action is dependent on the extent to which persons try to get their goal, along with their desire to do so. Generally, people refer to this psychological factor -the impulse that generates the action -as motivation. It is a motive force that arouses, incites, or stimulates action. Motivation is an important factor in specifying the readiness of learners to communicate.

In the teaching process, a teacher ought to be able to supply strategy of teaching English which can trigger students to explore their skill to and to construct students' personal understanding and experience.

However, the fact proves that the grade 6th students still have low motivation in learning English, even some of them are not interested or do not like to study English. This problem happens because some students think that English is a difficult subject to understand.

Furthermore, some teaching strategy applied by teachers could not burn out students' engagement in learning English. It could not invite students to actively participate in class; instead, they became bored and indolent to get involved in the learning activities. The teacher only gave the students copies of the text without introducing and explaining the text first.. When the students completed their task, the teacher handed over some questions and had them discuss the questions together. Such strategy was always demonstrated by the teachers over the teaching process. As a result, the students tended to be passive and found it difficult to advance in English.

Considering the conditions above, it is necessary to create innovation in teaching create attractive and efficient learning activities (Hasnah \& Ginting,2017). A good strategy should be able to involve both teacher and students and invited them to go along with the learning activities. To make the teaching process interesting and the purpose of the teaching-learning process achieved, teachers needed to apply an appealing strategy. An attractive strategy is essential to engage students to learn more enthusiastically. One of the strategies is cooperative learning. Cooperative learning is not just activity on students grouping or giving them the group task. An activity becomes cooperative learning when the learning environment is oriented to provide a mutually supportive activity between each student to each other. In this activity, students grow together in giving meaning to the contextual phenomena.

Cooperative learning has some important elements that characterized by positive interdependence, individual accountability, interaction each other, social skills, small groups and group process. Cooperative learning model is one learning model that promotes learning to know, learning to do, learning to be and learning to live together. This learning model can help students in enhancing students' positive attitudes to learn physics and can reduce or even eliminate student anxiety experienced when they learn physics. Interactions in groups give possibilities for students to adapt and to accept different ability and background of other students (Wyk, 2012). In addition, peer relationships are very important and cannot be underestimated. The peer encouragement to achieve better academic achievement not only foster well student motivation but also make students ready to work, and be attentive during learning and enhance the thinking ability (Hamid, Zakaria, \& Islam, 2012).

Cooperative learning is an effective way to structure and improve students' interactions/learning activities. There is a need for students to complete some or most of their homework/assignments in teams. The teams are encouraged to find solutions to academic problems/activities. The team gets a grade for the assignment and eventually, the performance of each team member should be assessed and the results used to adjust the average team homework grade separately for each team member. Adjusting team grades for individual performance is one of the principal ways of assuring individual accountability in cooperative learning and quality results.

\section{RELATED PREVIOUS RESEARCHES Cooperative learning}

This study examined the undergraduates' academic achievement in university the purpose of the study, three research questions and two hypotheses were posed. This study adopted a descriptive survey design and the population comprised the final year students of the Federal and State Universities in University of Port Harcourt, and Rivers State University of science and technology, Nigeria. There are seven thousand five hundred final year undergraduates in the 
P-ISSN: 2301-9913, E-ISSN: 2597-9132

DOI: http://dx.doi.org/10.31000/globish.v7i2

faculties of Education, Sciences, Humanities, Social Sciences and Engin stratified random sampling technique sample size, which represents $16 \%$ of the population..

The findings revealed among others that cooperatively taught students tend to exhibit higher academic achievement, greater persistence through graduation, better high-level reasoning and critical thinking skills, deeper understanding of learned materials, greater time on task and less disruptive behavior in class, lower levels of anxiety and stress, greater intrinsic motivation to learn and achieve, greater ability to view situations from others' perspectives, more positive and supportive relationships with peers, more positive attitudes toward subject areas, and higher selfesteem. Based on the findings, it was revealed that students should be encouraged to take active part in cooperative learning so as to promote better high level reasoning and critical thinking skills.

\section{Students' Motivation}

The problems of the research concerned with the elementary students' motivation in learning English. The study would like to find out the kinds of motivations they have and which kinds of motivation dominate them; integrative or instrumental motivation. The respondents of this study were sixty students of senior high schools in Pangkalpinang and nearby who enrolled in English Education Study Program in academic year 2013-2014.

This study used quantitative as well as descriptive method and is designed to find out some information from actual condition. Then, a set of questions or questionnaire was used to collect the data and then analyzed and computed the answers of the respondents to find out the value and mean value of each kind of motivation. Based on the result of the study, the researcher found that most of the students have little motivation in learning English. They tend to have instrumental motivation. They have enough self-confidence in understanding oral communication, reading, writing, and speaking but the aspect of culture is less exposed in English language learning.

The teachers of English should use the students' own motives for joining the course, encourage students to be active in the class by giving chance to suggest or giving opinion to solve problems in an experiment activity for instance, ask the students what type of teaching and learning which motivate them most and what kinds of classes which are not motivated them, encourage students to focus on their improvement not only grade or examination. The students can do self-assessment of their own work and find out their strength and weaknesses, encourage the students to work cooperatively in groups without pressure, give feedback without judging their mistakes and errors. Then, give reward which can establish their self-confidence and competence later.

\section{METHOD}

This study was designed through classroom action research comprising two cycles, and each cycle involved a plan, action, observation, and reflection. The subject of the research was fourty three students over one class. The data were collected by supplying test and observation. The data categorized into quantitative data gained from the test, and qualitative data were assembled from observation. The test was supplied at the end of each cycle to measure students' motivation in learning English. Besides, observation covered both students' learning and teacher's teaching activities. Quantitative was figured out through the formula $P=\frac{\mathrm{R}}{\mathrm{T}} \mathrm{x} 100 \%($ Arikunto, 2017)

\section{FINDINGS AND DISCUSSIONS}

This research was accomplished in two cycles. Every cycle was conducted in two meetings. Initially, preliminary observation and pretest were held to acquire information on students' motivation in learning English. The test result denoted that the students' motivation in learning English was classified into very low. On the other hand, the learning activity was passive. The teacher taught students with the monotonous strategy. In line with the condition, the teacher designed learning activities by employing cooperative learning strategy by using creative media . The planned strategy was then carried out by the teacher in teaching English, whereas researcher rolled as an observer, observing the whole processes of learning. After applying the strategy, the teacher gave the test. The test results and observation in the first cycle was made as a reference in designing the learning activity in the next cycle. 


\section{Cycle I}

In the first cycle, students' motivation in learning English improved significantly after receiving treatment through the use of cooperative learning strategy as proven from the different mean score of the test result in the first cycle about the number of students achieving the minimum score standard set by school (75). There were only 19 out of 43 students attaining 75 and over (44.18\%), while most of the students still have low motivation in learning English. They did not gave respond while the teacher asked them, they have less attention to the teacher and have no interest in learning English.

Additionally, the enhancement was identified from the learning process. Students' learning activity by using cooperative learning strategy was considered fairly active as exhibited in the following table.

Table 1

The score of Students' Learning Activity

\begin{tabular}{llc}
\hline No. & Aspect of Observation & Score \\
\hline 1 & Interest & $46.51 \%$ \\
2 & Attention & $62.79 \%$ \\
3 & Participation & $58.13 \%$ \\
4 & Presentation & $67.44 \%$ \\
\hline & Means & $58.72 \%$ \\
\hline
\end{tabular}

The table above displays that students' presentation in the learning process was figured out as the highest compared to the other aspects. The students were clearly done the presentation with pair students from the teacher. In contrast, the interest aspect was placed at the lowest as they were impassioned to answer teacher questions. They were more preferable to present their assignment in front of the class.

Similarly, the teacher's teaching activity progressed considerably. The development could be observed from the below table.

Table 2

The score of Teacher's Teaching Activity

\begin{tabular}{|c|c|c|}
\hline No & Aspect of Observation & Score \\
\hline 1 & Apperception & $68.50 \%$ \\
\hline 2 & Material Explanation & $65.70 \%$ \\
\hline 3 & Explanation of Strategy & $65.18 \%$ \\
\hline 4 & $\begin{array}{l}\text { The technique of Dividing } \\
\text { Group }\end{array}$ & $60.72 \%$ \\
\hline 5 & Classroom Management & $68.43 \%$ \\
\hline 6 & The Use of Media & $65.20 \%$ \\
\hline 7 & Voice & $63.76 \%$ \\
\hline 8 & Management of Discussion & $62.35 \%$ \\
\hline 9 & Guidance of Group & $59.67 \%$ \\
\hline 10 & Giving Question & $60.19 \%$ \\
\hline 11 & Ability to Evaluate & $62.37 \%$ \\
\hline 12 & Giving Reward & $58.81 \%$ \\
\hline 13 & Determining Score & $57.50 \%$ \\
\hline 14 & Concluding Learning Material & $64.78 \%$ \\
\hline
\end{tabular}


P-ISSN: 2301-9913, E-ISSN: 2597-9132

DOI: http://dx.doi.org/10.31000/globish.v7i2

\begin{tabular}{ll}
15 Closing & $65.12 \%$ \\
\hline Mean & $63.17 \%$ \\
\hline
\end{tabular}

The data above exposed the ability of teacher in applying cooperative learning strategy in teaching English. From the fifteen aspects, apperception was the most impressive in comparison with other forms, amounting $68.50 \%$, and followed by the other five facets; explanation of strategy at $65.18 \%$, and voice at $63.76 \%$ and closing with the amount at $65.12 \%$, whereas material explanation at $68.50 \%$ and concluding learning material reached $64.78 \%$. In contrast, giving question at $60.19 \%$ and determining score amounted at $57.50 \%$ considered as the lowest. From the data, it can be classified the teacher's teaching performance in cycle I very good.

Based on the result of the first cycle, it was still required to continue to the second cycle due to unsatisfactory students' motivation in learning English and teacher's teaching performance required to be improved.

\section{Cycle II}

The teaching and learning activities employing cooperative strategy along with instruments were arranged based on the reflection of the first cycle. As a result, students' motivation in learning English progressed substantially. The development was recognized from the distinctive mean score between the first and second cycle ranged from 60.94 to 81.26. In addition to the process of the learning process, students were more engaged to actively participate in the learning activity. Students' activity was noticed from four different aspects including Interest, Attention, Participation, and Presentation with the mean score at 78.62\%. Over the four attitudes, students' motivation in learning English was most highly reflected through interest achieving $83.71 \%$ and followed by $78.93 \%$ made up by attention facet. Meanwhile, two other aspects namely participation and presentation amounted to $76.35 \%$ and $75.50 \%$. The data were figured out in details as follow.

Table 1

The score of Students' Learning Activity

\begin{tabular}{llc}
\hline No. & Aspect of Observation & Score \\
\hline 1 & Interest & $83.71 \%$ \\
2 & Attention & $78.93 \%$ \\
3 & Participation & $76.35 \%$ \\
4 & Presentation & $75.50 \%$ \\
\hline & Means & $78.62 \%$ \\
\hline
\end{tabular}

Concerning teaching performance, the teacher could manage the class and perform more active and appealing learning activity.

Table 2

The score of Teacher's teaching Activity

\begin{tabular}{|c|c|c|}
\hline No & Aspect of Observation & Score \\
\hline 1 & Apperception & $92.24 \%$ \\
\hline 2 & Material Explanation & $88.79 \%$ \\
\hline 3 & Explanation of Strategy & $85.34 \%$ \\
\hline 4 & $\begin{array}{l}\text { The technique of Dividing } \\
\text { Group }\end{array}$ & $87.07 \%$ \\
\hline 5 & Classroom Management & $86.21 \%$ \\
\hline 6 & The Use of Media & $86.66 \%$ \\
\hline 7 & Voice & $81.03 \%$ \\
\hline 8 & Management of Discussion & $85.34 \%$ \\
\hline 9 & Guidance of Group & $84.48 \%$ \\
\hline 10 & Giving Question & $80.17 \%$ \\
\hline 11 & Ability to Evaluate & $73.28 \%$ \\
\hline
\end{tabular}




\begin{tabular}{lll}
12 & Giving Reward & $79.31 \%$ \\
13 & Determining Score & $79.31 \%$ \\
14 & Concluding Learning Material & $81.90 \%$ \\
15 & Closing & $84.48 \%$ \\
\hline & Mean & $83.91 \%$ \\
\hline
\end{tabular}

The table provides data that teacher's teaching performance in cycle two advanced notably in all aspects. Besides, the mean score of teacher's performances in class in the second cycle mounted to 83.91\% compared to cycle one at $63.17 \%$. so, students' motivation in learning English improved much better in cycle two than in cycle one.

\section{CONCLUSION}

After analyzing the data, it could be summarized that the implementation of cooperative learning strategy improved students' motivation in learning English. The students became more active and enthusiastic in learning English as well as in four skills. The enhancement could be identified from the difference of students' motivation in learning English scores between pre-test, collected before the treatment and post-test, tested after applying cooperative learning strategy through creative media in two cycles. Furthermore, the learning process became more active. The students were appealed to interest with the subject and exploited the information from the teacher through creative media. The improvement of students' learning could be observed from the average score of the four facets; interest, attention, participation, and presentation reaching $78.62 \%$ considered very good. In addition, the teacher's performance in teaching also experienced a very significant improvement. The teacher had been able to apply cooperative learning strategy successfully impacting on the student's motivation in the classroom being more interesting and active. This improvement was seen from the average value of observations in teacher's teaching performance hitting $83.91 \%$

\section{REFERENCES}

Alizadeh, Mitra. 2016. The Impact of Motivation on English Language Learning. Lahijan: Branch, Islamic Azad University, Lahijan,

Arikunto, S. 2007. Manajemen Penelitian. Jakarta: Rineka Cipta . 2015. Prosedur Penelitian Suatu Pendekatan Praktik. Jakarta: Rineka Cipta.

Nwabuze, Akachukwu. \& Igbinedion, Doye A. 2019. The Implications of Cooperative Learning Strategy on Students' Academic Achievements. Nigeria: University of Port Harcourt

Sulisworo, Dwi. \& Suryani, Fadiyah. 2019. The Effect of Cooperative Learning, Motivation and Information Technology Literacy to Achievement. Yogyakarta: University of Ahmad Dahlan

Wagiyo, Supiyah. 2018. Analysis of Students' Motivation in Learning English at Senior High School. Bangka Belitung: Islamic State University of Bangka Belitung 